\title{
INTERLENDING AND DOCUMENT SUPPLY: HOPES AND FEARS FOR 1992
}

\author{
Graham P. Cornish"
}

\begin{abstract}
Resumen: Con la creación en 1992 del Mercado Unico Europeo y la desaparición de muchas barreras ahora existentes, de mercado, de derecho de residencia y trabajo, etc. se abre la oportunidad de mejorar la circulación libre de documentos entre los países a través del préstamo interbibliotecario y las redes de suministro de documentos, pero todavía no hay signos inmediatos de unión monetaria que simplificaría el pago del intercambio internacional, y no parecen de solución inmediata los problemas de telecomunicación y servicios postales con diferentes precios y diferentes normas de servicio, así como los derivados de los derechos de autor. Otras barreras tales como los diferentes idiomas y el rechaso de los profesionales a cooperar internacionalmente no cambiarkn cor. la legislación comunitaria. Aunque 1992 traerá algunas mejoras, todavia hay un largo camino para recorrer.

Palabra Clave: Préstamo interbibliotecario, Suministro de documentos, Comunidad Europea, Mercado Unico Europeo.

Abatract: 1992 will bring the Single European Market in which many of the existing barriers to European integration will be removed. This applies not only to trade but free movement of goods, rights of residence and work and many other aspects of life. This should be an opportunity to improve the free flow of documents between countries through the interlibrary loan and document supply network. Customs barriers and restrictions on agency agreements for publishers may make life easier but there is no immediate sign of monetary union which would simplify the payment for international interlending transactions. However, many of the barriers that exist will not be removed by the changes in 1992. Problems will still exist with telecommunications and postal services with differing prices and, worse, differing standards of service. The difficult issue of copyright will not be resolved as the EC is not at present looking at reprography as an area of harmonization. Other barriers such as language and professional reluctance to cooperate internationally cannot be changed by legislation. Although 1992 may bring some improvements, there will still be a long way to go.

Keyworda: Interlending, Document supply, European Community, Single European Market.
\end{abstract}

\section{Introduction}

By the end of 1992 the members of the European Communities should be ready for a Single Market. Barriers will be removed to trade and commerce. Many of the regulations which inhibit the free flow of labour, such as rights of residence and work, will also be swept away. In many respects the EC members will become one huge entity. But nobody believes that all the barriers will go at once. Nobody believes that there will immediately be no impediments to free flow of labour. There are always problems to be solved before such grandiose schemes become a reality.

If this is so in those areas where the removal of barriers is planned, how much more will it be true for those areas where there are no such specific plans prepared. The whole question of interlibrary cooperation, not just interlending, is one which will face many problems within the EC before a single bibliotecal unity is achieved. It should be noted that the word "interlending" is used throughout this paper but "interlending and document supply" is what is meant on each occasion.

\footnotetext{
* Programme Officer. IFLA Programme for the Universal Availability of Publications (UAP)
}

Received 20-8-90 
Although this paper is primarily about 1992 , almost anything that is said about international interlibrary cooperation within the EC applies to a greater or lesser extent, to international interlending worldwide. Many of the problems, barriers and inhibitions are found throughout the world, not just in Western Europe.

\section{A Pan-European interlending system?}

Given the climate which 1992 is bringing about there is a temptation to see the whole of the EC as a huge oibliographic collection to which we all have easy and open, access. Just think of all those huge resources in the great libraries of Western Europe. How wonderful to have them all at our disposal to deal with the most esoteric needs of the most frustrated (and frustrating) reader.

But is this dream really a solution to a problem? Is there really a problem? Before either supporting or dismissing this dream, it is important to look at the fundamentals of any interlending system to see if 1992 will in any way improve the conditions necessary for any such system to flourish.

\section{It there a need?}

It there is no need for an interlending system, there is no need to create one. Although this is a self-evident statement, it needs to be made because there are numerous occasions when people have thought that an interlending system must be a "good idea" but, once created, it is hardly ever used. On the other hand, it is not always possible to measure need because the lack of a system will discourage people from making requests. Europe is a good area to study in this respect as most (though not all) countries have some sort of interlending system in place. So is there a need? A study carried out during $1989 / 90$ (1) showed that throughout Europe (all countries, not just the EC) the total turnover of international requests was 1.268.830. By this is meant the total number of requests made added to the total number of requests received. I use this method because the figures given in any survey for requests received far outnumber the figure for requests made. There are several reasons for this. In any study it is virtually impossible to identify every library so attention is paid to the larger libraries in any system. Such libraries are usually more able to respond to surveys and this leads to an imbalance between the number of requests made (many of which are not recorded) and the number received (most of which are recorded). If this theory is correct then most attention should be paid to the number of requests received by libraries. Even here there is a problem as an unknown number of requests may be sent to more than one library if the first library approached cannot satisfy the request.

Of these 1.268 .830 requests 987.611 or $77,8 \%$ of requests were to or from EC member countries although it is not possible to determine which were entirely intra-EC requests. Nevertheless, this shows a considerable volume of international traffic handled by EC member country libraries. It would seem reasonable to say that need has been demonstrated. 1992 will not change this.

But if there is a need, is it being met already? 


\section{Are users' needs being met?}

Success rates in this area should be very high if libraries are really observing the principles of Universal Availability of Publications (UAP). $40 \%$ of libraries achieved a success rate of at least $80 \%$ and only $11 \%$ reported a success rate of less than $50 \%$. In viewing these figures it must be remembered that these relate to requests received by particular libraries and that these failed requests may have subsequently been satisfied by another library. Nevertheless, there are a number or requests which do fail, possibly as many as $40 \%$ or, in EC terms, about 200.000 . So there is certainly room for improvement. One problem is simply knowing what is where. 1992 will not change this.

\section{Can materials be found?}

There are several ways of locating materials, ranging from the detailed union catalogues to the traditional card catalogue or the latest online systems. EC countries demonstrate everything within this range, often with a mixture within each country. In the UK, for example there are card catalogues, online systems, CD-ROM and printed union lists. In Belgium there is a CDROM catalogue, the Federal Republic of Germany has the Zeitschriftendatenbank on CD-ROM and online, in Denmark there are online systems and also a card catalogue, the Netherlands has Pica, France has its serials list on CD-ROM and Spain and Italy both have automated and traditional systems. In Portugal there is now Porbase. Greece has no union catalogue to speak of at all and no interlending system, either! The real problem is that there are a number of different systems but they are at present incompatible. Considerable importance should be attached to the work being done on OSI (Open Systems Interconnect) between the Netherlands, France and the UK, as this could prepare the way for a major pan-EC network of online databases and catalogues. In the area of finding out what is where there is a long way to go. Most EC countries do observe the UAP principle (that each country should niake its own publications available to any other country in the world) in theory but are unable to do so in practice because of their lack of systems. 1992 will not change this.

But it is of little use setting up complex systems to find out the location of material if the libraries or countries taking part do not have the materials which will enable a good system to operate effectively.

\section{Are the required materials held within the EC?}

Without good comprehensive collections which hold materials likely to be wanted through interlibrary loan, there is no point in having a system at all.

Fortunately EC countries are very well supplied with collections of outstanding national and international significance. All EC member countries have such libraries in quite large numbers and contribute significantly to the success of an interlending network. Even those countries with poor or nonexistent interlending systems have good collections to which access in needed. 
Special attention should be paid to less well-developed countries, otherwise there is a danger that good networks become even better whilst leaving the others even further behind. 1992 will not change this.

\section{Are materials available?}

Although it is clear that many libraries in EC do have the material needed by others and that there are mechanisms for locating that material, unfortunately it is not always the case that it can be made available in the way that readers hope. Fortunately most EC country libraries place relatively few restrictions on which materials they will make available through interlending. Obvious materials for restriction are reference materials, especially bibliographies and directories but other materials include old (however defined) materials, newspapers, audiovisual materials and unpublished documents. Very few libraries seem unwilling to supply documents to other libraries because of the country in which they are situated. In general availability within the EC is not a problem. 1992 does not need to change this!

An associated problem is how to get your request to the library that has the material you want. The whole problem of communications is dealt with later but there must be some kind of system to allow libraries to communicate with each other. The IFLA International lending: principles and guidelines for procedure which were first promulgated in 1979 and updated in 1987, suggest that there should be a single centre in each country to act as a focal point for international interlending requests. This is the case in the UK but certainly not so in many EC countries such as Netherlands, Belgium and Italy. Outside the EC many smaller countries do have a centre but the USA, for example, certainly does not and many countries are only too willing to allow libraries to deal directly without involving the national library or its equivalent. Where union catalogues or directories are good this need not be a problem but where it is difficult to identify major resources within a country, there should be a centre where knowledge of collections is maintained and requests from outside that country can be sent.

\section{Communications}

What is the point of having good collections, well documented, willingly made available to those who need them if there are real difficulties in communicating the need or transferring the material to satisfy it? The role of communications in interlending is crucial and this is an area where 1992 will not bring the changes needed to achieve our pan-European system.

It is increasingly easy to transmit requests between libraries. The normal postal services, which are of ten slow and unreliable, have been bypassed for some time by telex and even the telephone. With the outstanding growth in the use of telefacsimile (fax) requests can be transmitted within seconds. However, rather like some manufacturing processes in the industrial revolution, one side of the process does not keep up with the other. Transmission of documents between countries, even within the EC, is still slow and cumbersome. Photocopies can be sent by letter post and may take only a day or two, thus reducing the turnround between making the request 
and receiving the copy to as little as 3 days. This varies considerably from country to country and it must be acknowledged that postal services in Northern Europe are slightly quicker than those in South Europe. Nevertheless the transmission of the document is slower than the transmission of the request. Added to this must be the fact that postal charges vary considerably between countries and what may be quite cheap to send in one will be an expensive operation in another. Some libraries have turned to the transmission of high quality half-tones as well as straightforward text. In addition there are real problems with this which will be mentioned later. In the case of loans there are added problems. Not only is parcel post slow and very expensive, again with greatly varying charges, but it also entails adritional bureaucracy with customs of ficials. Hopefully 1992 will bring an end to some of the bureaucratic procedures but it will not solve the problems of differing postal tariffs.

The coming of the Single European Market could, and in the opinion of many people, should bring a common postal and telecommunications regime. This still seems a hope which is unlikely to be fulfilled. Failure to develop a European-wide postal system means that requests are more expensive to satisfy from some countries than others and market forces will drive libraries away from applying to those countries, even though they have better resources and a more efficient interlending system to deliver the goods.

Telecommunications also play a vital role in the online access to data which is crucial to the locating and ordering of material. Once again differing telecommunications charges makes it more expensive to search and apply to libraries outside the country from which the request comes. It seems unlikely that 1992 will change this.

Essential to communications is language. This is a difficult problem when dealing with a multilingual group of countries such as the EC. This is certainly an area where 1992 will bring no changes! Nevertheless, the problems must be addressed as international interlending relies on clearly understood messages, of ten of a highly complex nature. With the growth in online communications it is becoming easier to standardise and therefore translate the essential elements into whatever language, although this can of ten be expensive. Also it cannot solve the problems of special messages not dealt with by a predetermined coded system. One way round this is to encourage each country to standardise international (and national) interlending paperwork so that it can be understood, regardless of the language in which it is printed. In this respect the IFLA international loan/photocopy form provides a useful service, it is internationally recognised regardless of the language in which it is printed. It is customarily made available in an English/French version already although a German version also exists and other language versions are contemplated, especially in Japan and Yugoslavia.

\section{Finance}

Probably the biggest single barrier to international lending, whether in Europe or elsewhere, is money. The necessity to involve money in interlending takes more than one form and here it seems that 1992 will have only a partial role in solving the problems. 
There are number of problems associated with international interlibrary transactions which require any kind of monetary payment. Broadly speaking, these problems can be categorised as follows:

a) The small size of the transaction

b) Fluctuating exchange rates.

c) Libraries in countries where payment for library services is not recognised or allowed.

d) Libraries in countries where they may not retain money received as payment for services.

e) Libraries in countries where no hard currency is available.

f) Libraries without funds for interlibrary transactions.

g) Libraries without funds.

Not all of these problems arise in the EC and the coming of the Single European Market should solve one or two of them but there are still several which will not be changed in 1992 as they are essentially national or even regional or local problems.

Interlending in itself not big business. Each transaction is usually fairly small and, with the exception of major document supply centres or major national collections, usually with a range of different sources rather than with one or two large suppliers. Thus there are a lot of very small transactions to be carried out and paid for. Such transactions can cost far more in bank charges than the cost of actually supplying the document. One Austrian librarian complained that it was now cheaper to send postage stamps than get involved with money orders or bankers (2). Any moves towards a common currency, or at least some kind of interchangeability, must be welcomed by interlending librarians for this very reason. Similarly the problems associated with fluctuating exchange rates, making it difficult to predict just how much an interlending request will actually cost, would be reduced or removed if monetary union was to become a reality.

Although the question of hard currency does not arise within the EC, it is a serious problem for our near neighbours in Eastern Europe and monetary barriers of this kind will continue to inhibit international interlending for a long time to come. Far bigger problems are created for international interlending through national policies regarding charging, and more generally, government practice in relation to income by publicly-funded institutions.

In a number of countries both within the EC and outside it, the provision of library services is seen as a duty of the state and something which should be provided free of charge. The fact that a library does not have the item the reader wants is not the reader's fault and the library is not allowed to charge for a service which it would have provided free if its collections had been adequate to meet the needs of its clients. Consequently there is no budget for interlending in that library which means that any requests made outside the country for which payment must be made are of ten a severe burden on the finances of the libraries and have to be paid for out of some other expense heading or simply not made at all. Reciprocal arrangements may do something to alleviate this but it is unlikely that international interlending will of ten be in balance and eventually the payment will have to be made or interlending cease internationally for that library. 
Looked at from the other point of view, international interlending is quite an expensive operation and the expense cannot always be carried by the supplying library. Consequently supplying libraries make a charge to cover their costs. But in a number of countries any "revenue" received by public institutions is automatically handed over to the regional, state or federal government, leaving the supplying library to carry the total cost of the international interlending traffic which it satisfies. This means that some libraries either restrict or prohibit international interlending altogether. An associated problem is found where libraries may not charge for interlending, as already mentioned. As they have no money to pay for their own interlending requests, neither are they allowed to charge others for them which once again places considerable financial strains on them. Of course this is not just a library problem but a matter of national internal accounting procedures and government philosophy. Until something is done to harmonise such practices, there will continue to be a strain on international interlending relationships. If a method can be devised for reducing the number of monetary transactions, this will benefit libraries in some of the groups significantly. Any system should be global in nature and libraries in some groups would need assistance to "buy into" the system. However, once they become part of it, such a system would significantly reduce the costs of individual transactions thorough interlibrary loan to the benef it of the whole library community. Such a scheme has been suggested (3) and is currently being discussed.

\section{How it might work}

Value of the voucher

Vouchers would be sold by a central library "bank" at prices fixed for each individual country. Thus each voucher would be valued for a single transaction regardless of how much that transaction costs in each country. Interlibrary loan (or other interlibrary transactions) would be given a value in terms of local currencies but each transaction would cost only one voucher.

Thus a developing country would buy vouchers at, say $\$ 1$ and rich countries at, say $\$ 10$ and these would be redeemed at the same value in each case. This system will work only if:

a) the number of requests from developing countries is relatively low in global terms;

b) there is a grant for developing countries to buy into the system on a regular basis; and

c) the running costs of the scheme can be offset by the "bank" by using the unredeemed voucher money to generate interest to finance the scheme.

Mechanism for making requests

Vouchers should be sent with requests and retained by the supplying library. 
The same voucher or vouchers would be then used by that library when asking a request to another library and so on. There would be no exchange of money during the life of the voucher but only at the beginning of its circulating life (when a library buys into the system) and when it is finally redeemed for cash by a library which is a net supplier and has no further use for it. There is no intrinsic reason why this method cannot be used for electronic requesting and reply. A message mechanism would have to be set up to debit and credit accounts at the library "bank" or else a secure method of ensuring vouchers (or at least records of vouchers) were transmitted between requesting and supplying library. This could be done using unique numbering systems. Where fully electronic messaging is used then a system like credit cards can be initiated. Although there are still many questions to be answered, the basic idea has been well received and work continues on it. 1992 may solve some of these problems but not all of them.

\section{Legal Barriers}

Until a common Customs union is established throughout the EC there will continue to be delays in transmitting loans, especially if they are of microforms or non-print media. Delays and documentation seem interminable sometimes and cause considerable frustration to librarians and readers. A Single European Market should solve some, at least, of these problems for EC members but not for others!

Similarly the different copyright laws within the EC make it difficult to be sure that copies made in one country might not be infringing copies in another. What is permitted in one country will not be allowed in another, thus directing greater demands for photocopies to those countries with either a liberal or at least defined law as regards photocopying as opposed to those with unspecific laws or laws too old to address the issue properly. Harmonisation of legislation would do much to simplify life but it is important that the harmonisation takes place in such a way that libraries benefit rather than being put in a complete straightjacket. 1992 is unlikely to bring about any changes.

In looking at some of these problems it is worth noting that we are not battling alone in all of these areas. The Working Group of European Librarians and Publishers (4) has also addressed these topics and seen many of the same problems and hope for similar solutions. Librarians and publishers are sometimes seen on opposite sides of the "fence". This is one area where we can really cooperate to mutual advantage.

1992 will not solve all our problems but it should point the way to easing some of them. In looking at the problems we face within the EC it should always be remembered that these are, in fact, magnified many times, by librarians in developing countries where resources are scarce and the need to cooperate is considerable. Because of the lack of resources such expensive activities as international interlending have to be used with great care. Yet it is those who have least that need to have access to the rich resources of those who have much. 1992 may solve a few problems for us - it will do nothing for those outside and may even further limit their access to our rich and varied collections. 


\section{Bibliography}

1. CORNISH, G. P. Interlendins and document supply in Europe. Paris, Unesco, 1990. (PGI$90 / \mathrm{WS} / 13)$.

2. VARGA, J. Was tun gegen die Kostenexplosion im internationale leihverkehr? Mitteilungen der Vereinizung Osterreichischer Bibliothekare, 1988, 11 (1), 51-61.

3. CORNISH, G. P. Some realistic proposals to overcome the financial barriers to international supply. IFLA Journal, 1989, 15 (4), 313-319.

4. Working Group of European Librarians and Publishers (ELP) Barriers to the free flow of books. Amsterdam, ELP, 1990. 